\title{
Minimally Invasive Surgical Protocol for Adipose Derived Stem Cells Collection and Isolation - Ovine Model
}

\author{
HUSSAM AL HUSSEIN ${ }^{1,2}$, MARIUS HARPA ${ }^{1,2 *}$, IONELA MOVILEANU ${ }^{1,2}$, HAMIDA AL HUSSEIN ${ }^{1}$, HORATIU SUCIU1,2, \\ KLARA BRANZANIUC ${ }^{1,2}$, DAN SIMIONESCU ${ }^{3}$ \\ 'University of Medicine, Pharmacy, Science and Technology, Tissue Engineering and Regenerative Medicine Laboratory, 38 \\ Gheorghe Marinescu Str., 540142, Targu Mures, Romania \\ 2Emergency Institute for Cardiovascular Diseases and Transplantation, Cardiovascular Surgery Department, 38 Gheorghe \\ Marinescu Str., 540142, Targu Mures, Romania \\ ${ }^{3}$ Clemson University, Clemson, SC, USA
}

\begin{abstract}
Many methods of stem cells collection and isolation from various tissue types harvested either from small or large experimental animals or from human tissues have been published so far, all evaluating them as a potential source of adult mesenchymal stem cells with applicability in various pathologies or tissue bioengineering. The present study purposed to describe a minimally invasive surgical protocol for adipose tissue collection from sheep's inter-scapular area. The procedure was carried out on adultsheeps, in aseptic conditions. A light sedation protocol with Detomidine was performed, the recovery from anesthesia being carried out with Atipamezole. Throughout the sedation, the surgical procedure and the recovery from anesthesia, the vital functions of the animal were monitored. The adipose tissue samples collected in sterile tubes with culture medium (Dulbecco's modified Eagle's medium - DMEM/10\% / FBS10 - fetal bovine serum, 2\%antibiotic/antifungal), have been succesfully used by our research team for adipose tissue derived stem cells (ADSCS) isolation for further use in cardiac valves tissue engineering.
\end{abstract}

Keywords: adipose tissue, sheep, stem cells, Detomidine, Atipamezole

Many methods of stem cells isolation from various tissue types harvested either from small or large experimental animals or from human tissues have been published so far, all evaluating them as a potential source of adult mesenchymal stem cells with applicability in various pathologies or tissue bioengineering. Mesenchymal stem cells are characterized by the ability to renew and differentiate both into mesodermal tissues (osteoblasts, adipocytes, chondrocytes and myocytes) and other cell types, such as astrocytes and neurons [1-3]. In this regard, the isolation of mesenchymal stem cells from bone marrow $[4,5]$, adipose tissue [6-8], umbilical cord blood [9], peripheral blood [10,11], as well as from the amniotic fluid [12] and the dermal tissue [13] have been published.

Due to the easy protocol of collection, isolation and the great potential of proliferation and tissue differentiation in multiple cell lines, adipose tissue proved to be an attractive source of multipotent stem cells with potential use in regenerative medicine and tissue engineering [14]. From this point of view, the ovine model has been found to be of real importance in pre-clinical studies in the fields like orthopedic [15], uterine surgery [16] and heartvalves tissue engineering. Starting with the first collection and isolation of fat cells performed on mice by Rodbell [17], the method was applied thereafter to other animal models, being later modified for use in human models. [18] Benea et al (2018) found on a rabitt model that collagen scaffolds seeded with adipose stem cells derived from lipoaspirate fluid could be a valuable option in cartilage regeneration [19]. Hurmuz et al (2016) suggested that adipose stem cells derived from the human infrapatellar fat pad and isolated by a non-enzymatic method, have similar morphological and phenotypical characteristics with mesenchymal stem cells [20].

In 2017, Berea and colleagues obtained a 3D scaffoldfree construction with potential use in bone tissue engineering using a mixture of human ADSCs with Endothelial Cells and Fibroblasts [21]. Realizing the great regenerative potential of ADSCs, in 2016, Tremolada et al developed a new technology in which the fat tissue rezulted from lipoaspiration is washed and microfragmented without enzymes or other additives. They reported that the resulting product has been shown to have a great regenerative potential based on adipose derived mesenchymal stem cells, containing pericytes within an intact stromal vascular niche. Lipogems technology is acctually used with promising results in numerous clinical applications, plastic and reconstructive surgery and degenerative joints diseases [22] .

For decades, sheep have been chosen as one of the most used large animal model in the medical research, due to the similarities in size and phisiology to humans, but also for the easy handling during surgical procedures, unlike rodents [23].

Ovine subcutaneous fat tissue, regardless of the anatomical harvest area, is an attractive source of multipotent stem cells with a great regenerative potential and wide applicability in tissue engineering. According with Mrugala et al (2008), ovine ADSCs have similar properties and morphology to stem cells isolated from bone marrow. [24]

Grzesiak et al (2011) reported that adipose mesenchymal stem cells isolated from the sternum region have less differentiation potential comparing with those isolated from back, perineum or tail base, suggesting that the isolation from the ovine' sternum should be avoided [25].

In our investigation, after several harvesting attempts, performed by the research team from different anatomical regions (inter-scapular, paravertebral - lumbar and coccygeal, groin, perimammar, great omentum and perirenal), the most appropriate anatomical location for

*email: marius_harpa@yahoo.com, Phone.+40-740311396. 
collection and ADSCs isolation was the inter-scapular region. The harvesting region was chosen for several reasons: the easier access to the dorsal side of the animal on the operating table, a low infectious risk pre- and postoperatively (the ventral/inguinal region was avoided because of the high infectious potential), a better represented fat tissue at this level than other regions, such as the paravertebral area, and last but not least, a high consistency of viable cells [26].

This study aimed to present a minimally invasive surgical protocol used by our research team for adipose tissue collection and isolation of ADSCs in cardiac valves tissue regeneration.

\section{Experimental part}

Material and methods

The minimally invasive procedure was carried out on six adult sheeps, weight $20 \pm 3 \mathrm{~kg}$ age between 6 and 12 months. The surgical interventions were performed intravitally on light sedation, in aseptic conditions, at the Experimental Station of the University of Medicine and Pharmacy of Tg-Mures. The Ethics board of UMF Tg-Mures approved the study with the reference no.131/2016.

Anesthesia: For sedation, an $\alpha-2$ adrenoceptor agonist was used, intravenously Detomidine $(10-20 \mu \mathrm{g} / \mathrm{kg})$ and inhaled Sevoflurane subsequently by mask (fig. 2-a). The cardiopulmonary function was monitored during the surgery.
Protocol:The experimental animal was placed in lateral decubitus and the inter-scapular region was shaved and aseptisized with Betadine solution (fig. 2-b). After isolation with sterile fields, a $2 \mathrm{~cm}$ skin incision was performed with the subcutaneous dissection (fig. 2-c). Given that the stem cells in the adipose tissue are of pericytes type, the collection of a well-vascularised fat tissue was targeted. After the adipose tissue collection, ADSCs were isolated using the collagenase method: samples of $0.5-1 \mathrm{~cm}^{3}$ were collected in sterile tubes with culture medium DMEM/10\% / FBS10 -fetal bovine serum, $2 \%$ antibiotic/antifungal), (fig. 2 -d) the ADSCs being isolated and cultured in vitro as described by Zuk (2001) [29] and Gimble (2003) [3] for subsequent use in heart valves tissue regeneration. The ability of isolated cells to differentiate into multiple cell lines has been demonstrated by using differentiation kits (PromoCell, Inc) containing mixtures of growth factors causing adult stem cells to differentiate separately in adipocytes, osteoblasts and chondrocytes, this part of the research being described in another study published by our research team [30].

The procedure was finalized with the closure of the incision in anatomical plans, simple Blair-Donatti sutures being used (Prolene 4-0), (fig. 2-e), followed by wound disinfection with silver nitrate solution (fig. 2-f).

Recovery from anesthesia: For recovery from anesthesia, i.m. Atipamezole was used, in a dose of 1:1 relative to the Detomidine dose. An i.m. analgesic has also

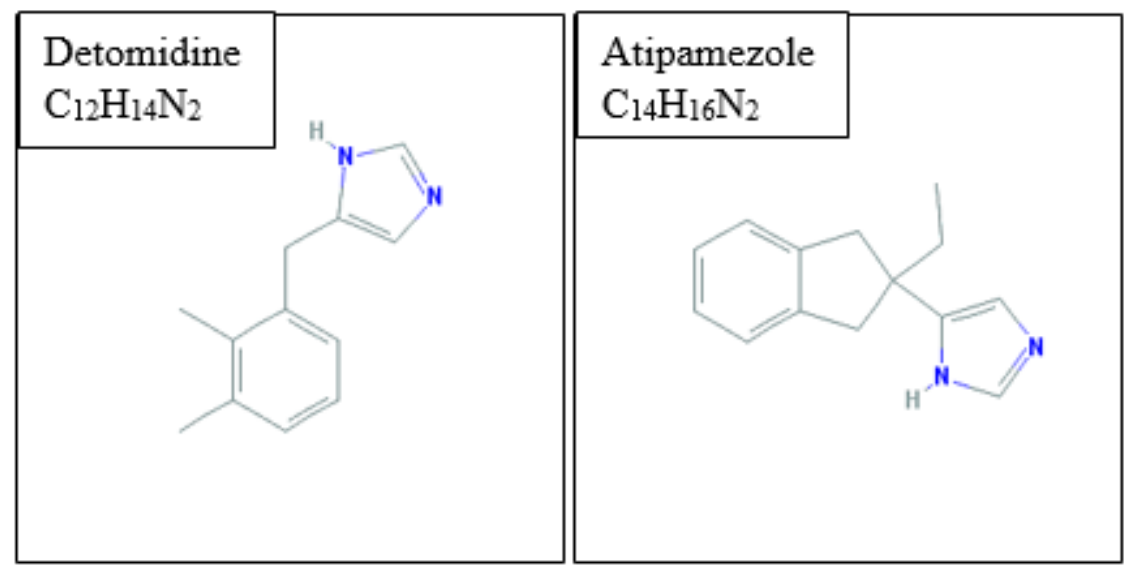

Fig. 1. The chemical structures of Detomidine and Atipamezole $[27,28]$

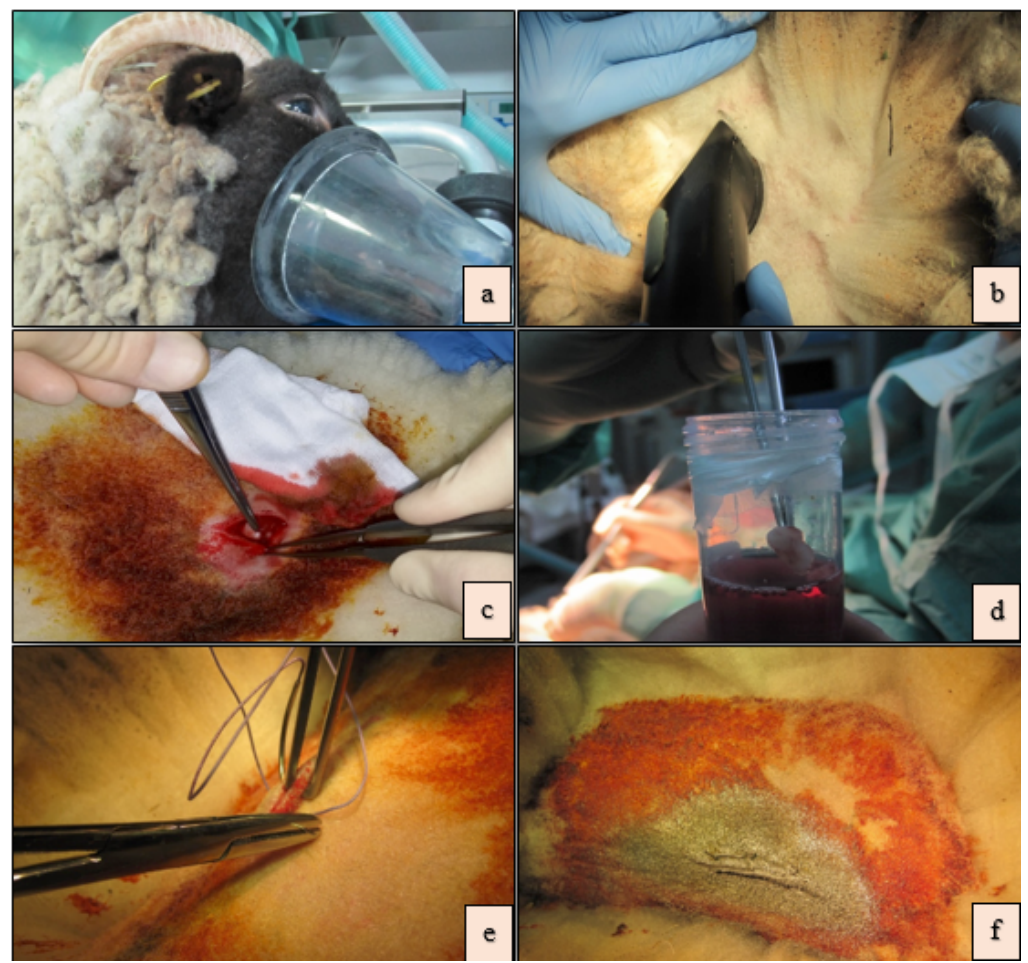

Fig. 2. Minimally invasive surgical protocol: a -sedation; b - preparing the inter-scapular region for incision; c - surgical incision for adipose tissue site accsesing; $d$ - adipose tissue samples collection in sterile tubes with culture medium; e - incision closure with simple sutures Blair-Donatti; $f$ - wound disinfection with silver nitrate solution. 
been administered, all this time, the animal's vital functions were monitored.

\section{Results and discussions}

During the sedation, no signs of bradycardia or hypotension were registered, common adverse events when using this type of anesthetic drugs in animals. Moreover, vomiting, muscle twitching or hypothermia were not registered as well after recovery from sedation. Atipamezole, an $\alpha$ adrenergic receptor antagonist, with a high specificity for the $\alpha_{2}$-adrenergic receptors, assured the reversal of sedative and analgesic effects of Detomidine, waking up the animals within $10 \mathrm{~min}$. It was not registered any case of postoperative wound infection or dehiscence, all experimental animals recovered quickly and favorably without any type of complication. The harvested adipose tissue was succesfully used for ADSCs isolation, resulting in 6 cell cultures. After 3 weeks cultivation, over 100 millions viable ADSCs were obtained.

Beaulah et al (2017) isolated adipose tissue derived mesenchymal stem cells (MSCs) from samples of subcutaneous, omental, renal, perineal and scrotal fat collected immediately after slaughter from adult sheep. They found plastic adherence 24 hours after seeding in (DMEM)-high glucose (DMEM-HG), regardless of the anatomical harvesting area [31].

Martinez-Lorenzo et al (2009), in their analysis of MSCs isolated from sheep, the adipose tissue was collected from the parapatellar area (medial approach), under general anesthesia (i.m ketamine, buprenorfin and propofol) [7]. Unlike Martinez-Lorenzo and his colleagues, in our protocol a light-sedation was performed, replacing the general anesthesia used by these authors. The administration of Detomidine, with sedative and analgesic properties [32], followed by inhaled Sevoflurane provided a light sedation with sufficient analgesia for carrying out the surgical procedure of harvesting adipose tissue samples.

Used in veterinary medicine mainly for large animals sedation, Detomidine has a sedative dose-dependent effect, causing a deep lethargy and lowering of the animal'a head. It is an arrhythmogenic agent having also an antidiuretic action Among the most important side effects could be mentioned high blood pressure, bradycardia, excessive sweating, salivation, muscle tremors [33].

Fadel et al (2011) collected adipose tissue from the perirenal region of female sheeps through a paracostal incision. They performed the procedure under general anesthesia with i.v propofol and fentanyl using as premedication i.v meperidine hydrochloride and midazolam, the anesthesia being maintained with inhaled isoflurane. In contrast with this study, the simplified anesthesia protocol we used in our research has ensured both a sufficient sedation as well as a quick and easy recovery from anesthesia by Atipamezole administration in a 1:1 dose relative to the Detomidine sedation dose. Unlike Fadel's report, in which a prophylactic antibiotherapy with penicillin was used for 5 days, in our research, the surgical wound was treated only with topical application of silver nitrate solution [8].

\section{Conclusions}

The proposed surgical protocol is an easily to perform and minimally invasive procedure for adipose tissue collection and ADSCS isolation, without postoperative complications. The anesthesia protocol provided the required sedation and analgesia during the surgery, ensuring as well a fast recovery of the experimental animals and without complications.
Acknowledgments: This work was supported by a grant from the Competitiveness Operational Programme 2014-2020, Tissue engineering technologies for cardiac valve regeneration, valve-regen, ID:P_37_673, Mysmis code:103431, contract 50/05.09.2016.

\section{References}

1.PITTENGER, M.F., MACKAY, A.M., BECK, S.C., et al., Science, 284, 1999, p. 143.

2.BOSSOLASCO, P., COVA, L., CALZAROSSA, C., et al, Exp Neurol, 193, 2005, p. 312.

3.GIMBLE, J., GUILAK, F., Cytotherapy, 5, 2003, p. 362.

4.REICHERT, J.C., WOODRUFF, M.A., FRIIS, T., et al, J Tissue Eng Regen Med, 4, nr. 7, 2010, p. 5 .

5.SANJURJO-RODRIGUEZ, C., et al, PLOS ONE, 12, nr. 1, 2017, p. e0171231. Academic OneFile, Accessed 17 Sept. 2018.

6.NIEMEYER, P., FECHNER, K., MILZ, S., et al, Biomaterials. 31, nr. 13, 2010, p. 3572.

7.J OSE MARTINEZ-LORENZO, M., ROYO-CANAS, M., ALEGREAGUARON, E., et al, J Orthop Res, 27, nr. 11, 2009, p. 1499.

8.FADEL, L., VIANA, B.R., TAJRA FEITOSA, M.L., et al, Acta Cir Bras, 26, no. 4, 2011, p. 267.

9.J AGER, M., BACHMANN, R., SCHARFSTADT, A., KRAUSPE, R., In Vivo, 20, no. 2, 2006, p. 205.

10.LYAHYAI, J., MEDIANO, D.R., RANERA, B., et al, Isolation and characterization of ovine mesenchymal stem cells derived from peripheral blood, Bmc Vet Res, 8, 2012, p. 169.

11.LANDA-SOLÍS, C., GRANADOS-MONTIEL, J., OLIVOS-MEZA, A., et al, Cell Tissue Bank., 17, nr.1, 2016, p. 137.

12.YUNYUN, T., LI, T., SIRIGULENG, Z., et al, Exp Anim, 65, no. 2, 2016, p. 125.

13.J AHROOMISHIRAZI, R., BADER, A., EBERT, S., et al, Cells Tissues Organs, 200, no. 2, 2014, p. 141.

14.FRASER, J.K., WULUR, I., ALFONSO, Z., HEDRICK, M.H., Trends Biotechnol, 24, no. 4, 2006, p. 150.

15.MANGGOLD, J., SERGI, C., BECKER, K., et al, Lab Anim, 36, 2002, p. 173.

16.DUNCOMBE, G.J ., BARKER, A.P., MOSS, T.J .M., et al, J Matern Fetal Neonatal Med, 11, no. 2, 2002, p. 130.

17.RODBELL, M., J Biol Chem, 241, 1966, p. 130.

18.VAN, R.L., BAYLISS, C.E., RONCARI, D.A., J Clin Invest, 58, 1976, p. 699.

19.BENEA, H.R.C., EARAR, K., LATTAZI, W., et al, Rev. Chim. (Bucharest), 69, no. 2, 2018, p. 515.

20.HURMUZ, M., BOJIN, F., IONAC, M., et al, Mater Plast, 53, no. 3, 2016, p. 553.

21.BEREA, G., BALAN, G.H., SANDRU, V., SIRBU, P.D., Rev.Chim. (Bucharest), 68, no. 6, 2017, p. 1341.

22.TREMOLADA, C., COLOMBO, V., VenturA, C., Curr Stem Cell Rep, 2, nr.3, 2016, p. 304.

23.SCHEERLINCK, J.P., SNIBSON, K.J ., BOWLES, V.M., SUTTON, P., Trends Biotechnol, 26, nr.5, 2008, p. 259.

24.MRUGALA, D., BONY, C., NEVES, N., et al, Ann Rheum Dis, 67, nr.3, 2008, p. 288.

25.GRZESIAK, J., KRZYSZTOF, M., KAROL, W., CZOGAfA, J., Int J Stem Cells, 4, no. 2, 2011, p. 99.

26.HARPA, M.M., BRÎNZANIUC, K., SUCIU, H., COTOI, O., MOVILEANU, I., SIMIONESCU, D., Studii experimentale de bioinginerie tisulara in chirurgia cardiaca valvulara, Editura University Press, Tg-Mures, 2017, p. 45-47.

27.***https://pubchem.ncbi.nIm.nih.gov/compound/ detomidine\#section=Top

28.*** https://pubchem.ncbi.nlm.nih.gov/compound/Atipamezole 29.ZUK, P.A., ZHU, M., MIZUNO, H., et al, Tissue Eng. 7, no. 2, 2001, p. 211.

30.HARPA, M.M., MOVILEANU, I., SIERAD, L.N., et al, RJLM, 23, no. 4, 2015, p. 415.

31.BEAULAH, V., USHAKUMARY, S., KANNAN, T.A., et al, J. Indian J. Anim. Res., 51, no. 2, 2017, p. 340.

32.ENGLAND, G.C., CLARKE, K.W., Br Vet J, 152, no. 6, 1996, p. 641. 33.*** http://www.hmdb.ca/metabolites/HMDB0041872 